MOHAMMAD MAGHROUR ZEFREH, Ph.D. Student ${ }^{1}$

E-mail: mohammad.maghrour@mail.bme.hu

FERENC MESZAROS, Ph.D. Ing. ${ }^{1}$

E-mail: fmeszaros@kgazd.bme.hu

RAIMUNDAS JUNEVIČIUS, Ph.D. Ing. ${ }^{2}$

E-mail: raimundas.junevicius@vgtu.It

ADAM TOROK, Ph.D. Ing., Ph.D. Eco. ${ }^{1}$

(Corresponding author)

E-mail: atorok@kgazd.bme.hu

1 Budapest University of Technology and Economics,

Department of Transport Technology and Economics

Stoczek utca 2, 1111 Budapest, Hungary

2 Vilnius Gediminas Technical University,

Faculty of Transport Engineering,

Department of Transport Technological Equipment

J. Basanavičiaus str. 28, 03224 Vilnius, Lithuania
Traffic in the Cities

Preliminary Communication

Submitted: 23 Feb. 2016

Accepted: 21 Sep. 2016

\title{
ECONOMIC INVESTIGATION OF A PUBLIC TRANSPORT SUPPORT POLICY: A CASE STUDY AT BUDAPEST
}

\begin{abstract}
This paper analyses the effect of supporting the public transport policy based on intersection controlling with the aim of tram priority in Budapest, as a case study. The hypothesis related to this study was that the support of public transport is only viable when the marginal benefit of public transport is higher than the marginal cost of individual transport. Therefore, the real costs of this support for the society were estimated. This study revealed that by applying this policy, the waiting time at intersections and $\mathrm{CO}_{2}$ emission-related costs have increased by about $13.7 \%$ and $14.2 \%$, respectively. Besides, the estimated monetary gain of tram users would be 17,800 euro on a daily level total by applying the mentioned policy.
\end{abstract}

\section{KEY WORDS}

public transport support policy; social costs; intersection controlling; $\mathrm{CO}_{2}$ emission cost;

\section{INTRODUCTION}

The transport policy in most of the countries states that the transport system should be designed in order to contribute to a shift towards sustainable society. An important part of the official policy is that pricing in the transport sector should be efficient, i.e. prices should equal the marginal costs (including environmental costs caused by transportation) and that changes in the transport system (including investments) should be appraised through the use of cost-benefit analysis [1]. Policy interventions in the transport sector are accompanied by risks and uncertainties, which become visible in the form of unintended effects [2]. These effects can lead to a deviation from the initial policy objective or even be counter-intentional [3]. Single policies or entire policy packages are often assessed using different methods aiming at a quantification of effects as well as the detection of undesired outcomes. The knowledge of potential impacts is essential to take informed policy actions [3]. There are a number of studies in the literature that assessed the impact of transport policies. For instance, Tobollik et al. studied the impact of transport policies and mostly its related air pollution on health using particulate matter $(<2.5$ $\mu \mathrm{m}$ in aerodynamic diameter $\mathrm{PM}_{2.5}$ ) and elemental carbon (EC) [4]. Verma et al. assessed the sustainability impact of transportation policies in Bangalore city [5]. Sun et al. evaluated the low-carbon transport policies based on multi-actor multi-criteria analysis (MAMCA) in Tianjin [6]. Crisalli et al. presented a methodology to evaluate rail-road freight policies such as new services and/or incentives for long-distance freight transport by using a mixed what-if/what-to approach. It uses a specific mode-service choice model to share the freight demand among alternatives (rail-road combined transport, maritime Ro-Ro and road transport) and a service network design model to identify new rail-road freight services [7]. Wang et al. assessed transport policies implementation using two accessibility indicators (i.e., potential and adaptive accessibility) in land use and the transport interaction (LUTI) model [8]. The European Commission white paper (2011) proposed that congestion in the European Union (EU) is often located in and around urban areas and costs nearly 100 billion euro (or $1 \%$ of the EU's GDP) annually [9]. Public transport support policies will be mostly done in order to reduce congestion and subsequently decrease the social costs of transportation by increasing the efficiency of public transportation and shifting commuters from private cars to public transport. In this paper, the effect of supporting public transport policy based on intersection controlling with the aim of tram priority has 
been analysed in order to investigate whether this public transport support policy really decreased the social costs of transportation or not. The research area was Budapest. The hypothesis related to this study was: the support of public transport is only viable when the marginal benefit of public transport supporting policy is higher than the marginal cost of individual transport punishment. Wei et al. research proposed a methodology to assess the urban carrying capacity [10]. In this paper, the authors focused only the urban transportation and the balance between public transportation and private cars. Nowadays, intersection controlling is not only a tool for lower emission level but also a tool for promoting sustainable mobility inside the city. Cerny et al. showed suitable theoretical findings as a support for decision-making on economic sustainability and accessibility of public transport [11]. Tosa et al. in their publications, investigated the occurrence of the vehicle engine pollution appearance taking into account velocity and street loading [12].

Modal shift [13] from private car use to public transport is not only important for EU $[14,15]$ but on a smaller scale as a city, it is very important for building a liveable city [16]. There are known policy tools for public transport support strategies [17] or advanced information services for public passengers [18]. In this paper, a case study was analysed in Budapest. The results could be interesting not only for Hungary but worldwide as well.

Figure 1 shows a ring in Budapest with two lanes in the opposite direction and two opposite lanes for tram service. There are different intersection control possibilities [19]. Until 2012, there was a synchronised green-wave through the ring with the periodicity of 90 seconds that gave advantages to private car users as a green wave with the designed speed of $50 \mathrm{~km} / \mathrm{h}$. In 2012, the synchronisation controlling policy changed to 60 seconds of periodicity. Since then a new controlling policy has been used that supports the trams instead of private cars. To gain more advantages for tram priority, the synchronisation of intersections was based on the tram schedule. The phases of individual intersections were synchronised in order to develop intersection optimum to reach the network optimum [20] in travel time minimization on the tram. Therefore, the travel time was shortened by 2-3 minutes. The total project cost 176,000 euro of which 160,000 euro were funded by the European Union [21]. To the best of the authors' knowledge, the related international literature has not been taking into account the cross-effect of support of public transport. The competition of individual private cars and public transport has some negative effects on the private car usage in the case of urban environment [22]. But yet, no one has estimated the real costs of this support to society. In this paper, the social costs of public transport support in Budapest were estimated. Our hypothesis is that the support of public transport is viable only when the marginal benefit of public transport is higher than the marginal cost of individual transport.

\section{METHODOLOGY}

The full costs of transportation are usually categorized as direct and indirect costs. Direct costs (sometimes also called private or internal costs) include the costs that car users directly consider in making a trip, such as vehicle operating cost, car depreciation, cost

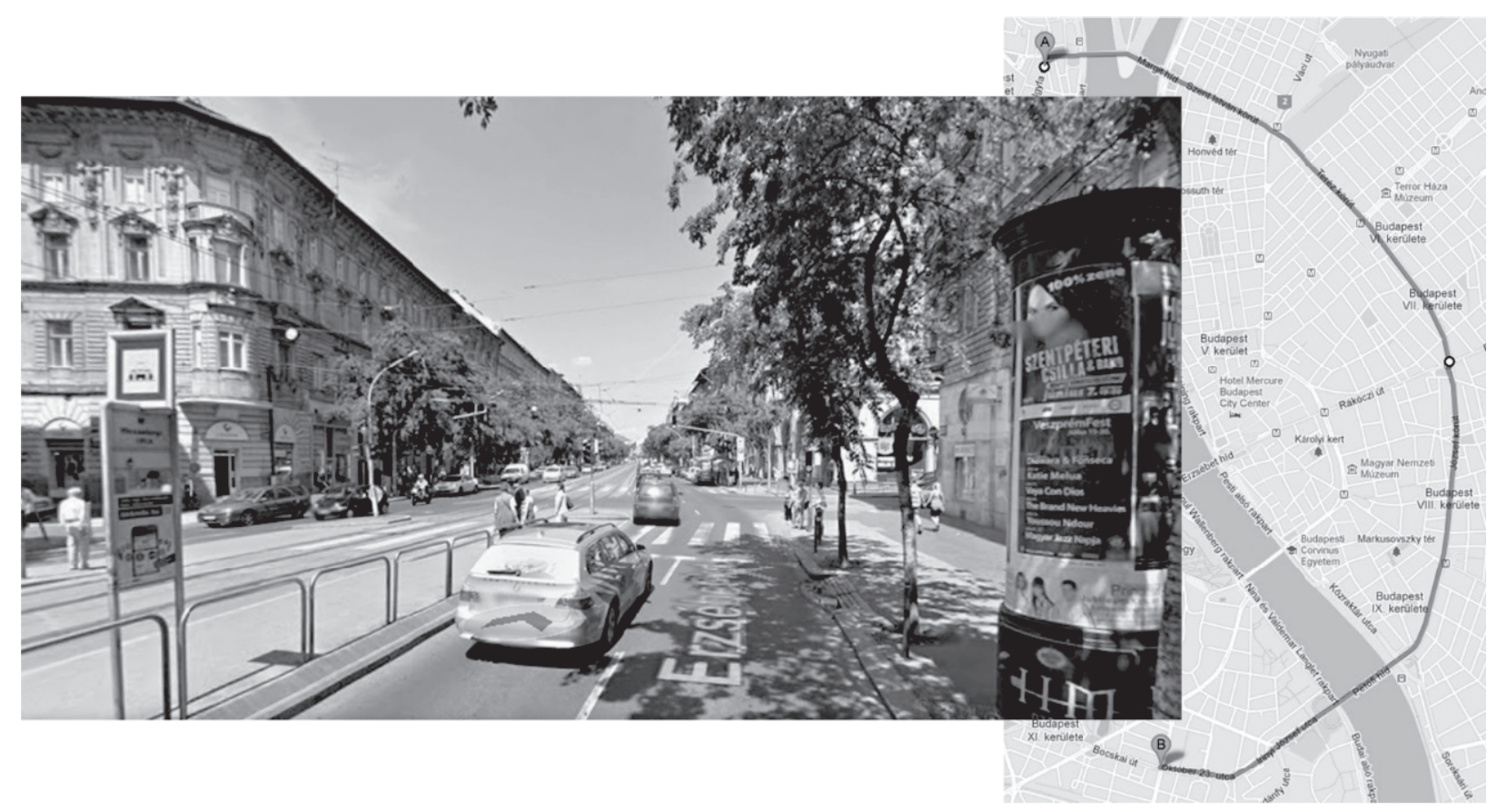

Figure 1 - Area of investigation in Budapest 
of fuel consumption, time lost in traffic, tolls and other parking fees, etc. Indirect costs (also called social or external costs), on the other hand, refer to the costs that car users are not held accountable for. These include the congestion costs that every user imposes on the rest of the traffic, costs of accidents, and costs of air pollution and noise [23]. Among these socalled external costs in this paper the cost of fuel consumption (cost of related $\mathrm{CO}_{2}$ emission) and cost of time lost were respectively calculated and compared before and after applying the previously mentioned public transport support policy. In this paper, the marginal costs/benefits of individual/public transport is considered as the change in the entire average perceived costs plus external costs of individual/public transport. Since the average perceived costs will not be significantly changed (if not unchanged), due to a tiny increase in the average intersection waiting time, the modal change from private to public transport is basically included in this assumption considering the change in external costs/benefits of individual/public transport. In this study, a detailed traffic counting was done on an hourly basis on the tram line and in each lane before and after the change of synchronisation method of signals.

Table 1 - Result of traffic counting [PCU/h] for individual road transport
Based on this hourly counting (Table 1) the hourly social costs (based on the emissions and value of travel time and changes in travel time) of private cars [24] and tram users (based on the value of travel time and changes in travel time) can be estimated [25]. The tram users were also surveyed. The result of surveying was that the tram users travel average 6 stops and the average flow was 8,000 persons/h/direction. Private cost surplus based on fuel consumption:

$C_{\text {fuel }}=\left(\sum_{i=1}^{m} c_{i} \cdot t\right) \cdot v_{j}$

where:

$C_{\text {fuel }}$ - private cost of fuel consumption surplus [€/h];

$c_{i} \quad$-idle fuel consumption of vehicle $i$ [litre/h] based on the statistical value of Hungarian vehicle fleet consumption analysis [26];

$t$-sum of red times in one hour [h/h];

$v_{j} \quad$ - cost factor of fuel $j[€ /$ litre].

From the elapsed time in the intersection where the engine is in idle mode, the $\mathrm{CO}_{2}$ emission can be calculated based on the fuel consumption.

Emission-based hourly social cost estimation:

$\mathrm{C}_{\mathrm{CO}_{2}}=\left(\sum_{i=1}^{m} e_{i} \cdot t\right) \cdot v$

\begin{tabular}{|c|c|c|c|c|c|c|c|c|c|}
\hline \multicolumn{10}{|c|}{ Blaha Lujza tér northwards [PCU/h] } \\
\hline $6: 00$ & $7: 00$ & 8:00 & 9:00 & $14: 00$ & $15: 00$ & $16: 00$ & $17: 00$ & $18: 00$ & 19:00 \\
\hline 774 & 1,222 & 1,280 & 1,365 & 1,321 & 1,309 & 1,372 & 1,450 & 1,353 & 1,268 \\
\hline \multicolumn{10}{|c|}{ Blaha Lujza tér southwards [PCU/h] } \\
\hline $6: 00$ & $7: 00$ & 8:00 & 9:00 & $14: 00$ & $15: 00$ & $16: 00$ & $17: 00$ & $18: 00$ & 19:00 \\
\hline 816 & 1,396 & 1,382 & 1,205 & 1,264 & 1,270 & 1,352 & 1,908 & 2,347 & 2,089 \\
\hline \multicolumn{10}{|c|}{ Boráros tér northwards [PCU/h] } \\
\hline $6: 00$ & 7:00 & 8:00 & 9:00 & $14: 00$ & $15: 00$ & $16: 00$ & $17: 00$ & $18: 00$ & 19:00 \\
\hline 756 & 1,191 & 1,120 & 1,117 & 869 & 1,009 & 1,223 & 1,164 & 1,120 & 895 \\
\hline \multicolumn{10}{|c|}{ Boráros tér southwards [PCU/h] } \\
\hline $6: 00$ & $7: 00$ & 8:00 & 9:00 & $14: 00$ & $15: 00$ & $16: 00$ & $17: 00$ & $18: 00$ & 19:00 \\
\hline 1,341 & 2,409 & 2,315 & 2,176 & 1,730 & 1,848 & 1,739 & 1,725 & 1,758 & 1,706 \\
\hline \multicolumn{10}{|c|}{ Széll Kálmán tér northwards [PCU/h] } \\
\hline $6: 00$ & $7: 00$ & $8: 00$ & 9:00 & $14: 00$ & $15: 00$ & $16: 00$ & $17: 00$ & $18: 00$ & 19:00 \\
\hline 1,058 & 1,725 & 1,728 & 1,681 & 1,688 & 1,824 & 1,758 & 1,704 & 1,701 & 1,567 \\
\hline \multicolumn{10}{|c|}{ Széll Kálmán tér southwards [PCU/h] } \\
\hline $6: 00$ & $7: 00$ & 8:00 & 9:00 & $14: 00$ & $15: 00$ & $16: 00$ & $17: 00$ & $18: 00$ & 19:00 \\
\hline 465 & 953 & 976 & 921 & 916 & 1,014 & 1,078 & 896 & 677 & 715 \\
\hline \multicolumn{10}{|c|}{ Budafoki-Október 23. utca northwards [PCU/h] } \\
\hline $6: 00$ & $7: 00$ & $8: 00$ & 9:00 & $14: 00$ & $15: 00$ & $16: 00$ & $17: 00$ & $18: 00$ & 19:00 \\
\hline 1,074 & 1,795 & 1,936 & 1,751 & 1,663 & 1,739 & 1,592 & 1,512 & 1,752 & 1,503 \\
\hline \multicolumn{10}{|c|}{ Budafoki-Október 23. utca southwards [PCU/h] } \\
\hline $6: 00$ & 7:00 & 8:00 & 9:00 & $14: 00$ & $15: 00$ & $16: 00$ & $17: 00$ & $18: 00$ & $19: 00$ \\
\hline 758 & 1,282 & 1,278 & 1,276 & 1,315 & 1,359 & 1,223 & 1,315 & 1,226 & 1,084 \\
\hline
\end{tabular}


where:

$\mathrm{C}_{\mathrm{CO}_{2}}$-emission-based hourly social cost estimation $[€ / \mathrm{h}]$;

$e_{i} \quad$-idle $\mathrm{CO}_{2}$ emission of vehicle $i\left[\mathrm{tCO}_{2} / \mathrm{h}\right]$ based on the statistical value of Hungarian vehicle fleet consumption analysis [26];

$t \quad$-sum of red times in one hour $[\mathrm{h} / \mathrm{h}]$;

$v \quad$-cost factor of $\mathrm{CO}_{2}\left[€ / \mathrm{tCO}_{2}\right]$.

The value of travel time and changes in travel time were estimated for both tram users and car users as follows:

$$
T T C=\left(\sum_{j=1}^{n} N_{j} \cdot \Delta T T\right) \cdot \tau
$$

where:

TTC - social cost of travel time change $[€ / \mathrm{h}]$;

$N_{j} \quad$-number of passengers;

$\Delta T T$-change in travel time in one hour [h/h] please note that it can be positive or negative, depends on tram or private car usage in this case;

$\tau \quad$-monetary value of travel time [€/h] [26].

It should be mentioned that the red times of intersections were known from the phase-plane of the intersection before and after the change.

\section{RESULTS}

In Table 2 the intersections were investigated based on their red times by the new and old controlling policies.

Taking Table 1 into account, the average increase of intersection waiting time is less than four seconds. In fact, the costs that travellers will consider in their own travels (the so-called perceived average generalized costs) will not change since this time increment is insignificant for travellers. The thing which is of great importance here is the increase of external costs. Therefore, as people just consider their own costs and not the costs they will impose on the rest of the society, the modal split will not be changed.

Based on [26] and Equation 1 that considers waiting in intersection with idle engine, the cost of fuel consumption surplus can be estimated (Table 3).

Based on [26] and Equation 2 that considers waiting in intersection with idle engine, the cost of $\mathrm{CO}_{2}$ emission and resulting social costs can be estimated (Table 4).

Based on [26] and Equation 3 that considers waiting in intersection, the cost of change in travel time can be estimated (Table 5).

\section{ANALYSIS AND DISCUSSION}

As it can be seen from Table 2, the waiting time in intersections was increased from total $431 \mathrm{sec}$. to total $490 \mathrm{sec}$. This is an increase of $59 \mathrm{sec}$ which is $13.7 \%$. In a real condition, the increase is higher because of the more stop-and-go situation.

From Table 3 it can be stated that the $\mathrm{CO}_{2}$ related social costs were increased by the newly implemented controlling policy. In the investigated period in the peak hour with the old strategy, the average social costs were approximately $4.5 €$ /hour in each direction for petrol driven cars and were approximately $1.7 € /$ hour in each direction for diesel oil driven cars. With the new public transport supporting policy, the average approximated social cost in peak hour was increased to $5.2 € /$ hour in each direction for petrol driven cars and $2 € /$ hour in each direction for diesel oil driven cars. In total, this is about $14 € /$ peak hour $\mathrm{CO}_{2}$

Table 2 - Length of red times [s]

\begin{tabular}{||c|c|c|l||}
\hline $\begin{array}{c}\text { No. of } \\
\text { intersection }\end{array}$ & $\begin{array}{c}\text { Old } \\
\text { controlling policy }\end{array}$ & $\begin{array}{c}\text { New } \\
\text { controlling policy }\end{array}$ & \multicolumn{1}{||}{ Description } \\
\hline \hline 1 & 20 & 5 & II. Margaret bridge Buda side \\
\hline 2 & 12 & 23 & XIII. Margaret Island \\
\hline 3 & 17 & 26 & XIII. Jászai Mari sqr \\
\hline 4 & 35 & 34 & VI, Nyugati Railwaystation \\
\hline 5 & 64 & 35 & VI. Oktogon sqr \\
\hline 6 & 17 & 39 & VI. Wesselényi str \\
\hline 7 & 15 & 34 & VII. Király str \\
\hline 8 & 35 & 24 & VII. Blaha Lujza sqr \\
\hline 9 & 15 & 50 & VIII. Rákóczi sqr \\
\hline 10 & 44 & 26 & VIII. Baross str \\
\hline 11 & 61 & 25 & VIII. Corvin sqr \\
\hline 12 & 32 & 33 & IX. Mester str \\
\hline 13 & 20 & 48 & IX. Boráros sqr \\
\hline 14 & 12 & 33 & XI. Petöfi bridge, Buda side \\
\hline 15 & 32 & 20 & XI. Budafoki str \\
\hline 16 & - & 35 & XI. Fehérvári str - Not existed in the old controlling policy \\
\hline
\end{tabular}

Source: BKK Centre for Budapest Transport 
related social cost caused only by private cars in the investigated area (see Table 4).

Although the potential energy saving in Europe in the transportation sector is about $26 \%$ reduction in energy consumption [27], by applying this policy not only more fuel consumption has negative effects on the social level through more $\mathrm{CO}_{2}$ emissions, but also on the private level a surplus in fuel consumption.
An average $30 € / h$ surplus of consumption-related private costs has been caused by changing the control policy (based on Table 3). According to the Hungarian tax regulation on fuel consumption, this could cause approximately $12 € / \mathrm{h}$ more tax based on the fuel consumption surplus.

It can be stated from Table 5 that the total social cost for private car users based on monetary value of

Table 3 - Private cost of fuel consumption in red time in idle mode [€/h]

\begin{tabular}{|c|c|c|c|c|c|c|c|c|c|c|c|c|}
\hline \multicolumn{2}{|c|}{ Gasoline } & $6: 00$ & $7: 00$ & 8:00 & 9:00 & $14: 00$ & $15: 00$ & $16: 00$ & $17: 00$ & 18:00 & 19:00 & Sum \\
\hline \multirow{2}{*}{ Old } & to North & 97 & 160 & 171 & 169 & 158 & 167 & 171 & 166 & 169 & 153 & 1,581 \\
\hline & to South & 92 & 167 & 180 & 169 & 159 & 166 & 165 & 174 & 174 & 161 & 1,607 \\
\hline \multicolumn{2}{|c|}{ Sum } & 189 & 327 & 351 & 338 & 318 & 333 & 336 & 341 & 343 & 313 & 3,188 \\
\hline \multirow{2}{*}{ New } & to North & 111 & 183 & 196 & 193 & 181 & 190 & 195 & 190 & 193 & 174 & 1,806 \\
\hline & to South & 105 & 191 & 205 & 193 & 182 & 189 & 189 & 199 & 198 & 184 & 1,836 \\
\hline \multicolumn{2}{|c|}{ Sum } & 216 & 374 & 401 & 386 & 363 & 380 & 384 & 389 & 391 & 358 & 3,642 \\
\hline \multicolumn{2}{|c|}{ Diesel oil } & $6: 00$ & $7: 00$ & $8: 00$ & 9:00 & $14: 00$ & $15: 00$ & $16: 00$ & $17: 00$ & $18: 00$ & $19: 00$ & Sum \\
\hline \multirow{2}{*}{ Old } & to North & 33 & 54 & 58 & 57 & 54 & 56 & 58 & 56 & 57 & 52 & 536 \\
\hline & to South & 31 & 57 & 61 & 57 & 54 & 56 & 56 & 59 & 59 & 54 & 545 \\
\hline \multicolumn{2}{|c|}{ Sum } & 64 & 111 & 119 & 114 & 108 & 113 & 114 & 116 & 116 & 106 & 1,080 \\
\hline \multirow{2}{*}{ New } & to North & 38 & 62 & 66 & 65 & 61 & 64 & 66 & 64 & 65 & 59 & 612 \\
\hline & to South & 36 & 65 & 70 & 65 & 62 & 64 & 64 & 67 & 67 & 62 & 622 \\
\hline \multicolumn{2}{|c|}{ Sum } & 73 & 127 & 136 & 131 & 123 & 129 & 130 & 132 & 133 & 121 & 1,234 \\
\hline
\end{tabular}

Table 4 - Sum of $\mathrm{CO}_{2}$ emission-related costs/hour in red [€/h] (calculation was done on $20 \mathrm{EUR} / \mathrm{tCO}_{2}$ )

\begin{tabular}{|c|c|c|c|c|c|c|c|c|c|c|c|c|}
\hline \multicolumn{2}{|c|}{ Gasoline } & $6: 00$ & 7:00 & 8:00 & 9:00 & $14: 00$ & $15: 00$ & $16: 00$ & $17: 00$ & $18: 00$ & 19:00 & Sum \\
\hline \multirow{2}{*}{ Old } & to North & 2.58 & 4.25 & 4.54 & 4.47 & 4.21 & 4.42 & 4.53 & 4.42 & 4.48 & 4.05 & 41.95 \\
\hline & to South & 2.45 & 4.43 & 4.77 & 4.49 & 4.23 & 4.40 & 4.39 & 4.63 & 4.61 & 4.26 & 42.65 \\
\hline \multicolumn{2}{|c|}{ Sum } & 5.03 & 8.68 & 9.31 & 8.96 & 8.43 & 8.82 & 8.92 & 9.04 & 9.09 & 8.31 & 84.60 \\
\hline \multirow{2}{*}{ New } & to North & 2.95 & 4.85 & 5.19 & 5.11 & 4.80 & 5.05 & 5.17 & 5.05 & 5.12 & 4.63 & 47.91 \\
\hline & to South & 2.79 & 5.06 & 5.45 & 5.13 & 4.83 & 5.03 & 5.01 & 5.28 & 5.27 & 4.87 & 48.71 \\
\hline \multicolumn{2}{|c|}{ Sum } & 5.74 & 9.91 & 10.64 & 10.23 & 9.63 & 10.08 & 10.18 & 10.33 & 10.39 & 9.50 & 96.63 \\
\hline \multicolumn{2}{|c|}{ Diesel oil } & 6:00 & $7: 00$ & 8:00 & 9:00 & $14: 00$ & $15: 00$ & $16: 00$ & $17: 00$ & $18: 00$ & 19:00 & Sum \\
\hline \multirow{2}{*}{ Old } & to North & 0.96 & 1.57 & 1.68 & 1.66 & 1.56 & 1.64 & 1.68 & 1.64 & 1.66 & 1.50 & 15.54 \\
\hline & to South & 0.91 & 1.64 & 1.77 & 1.66 & 1.57 & 1.63 & 1.62 & 1.71 & 1.71 & 1.58 & 15.80 \\
\hline \multicolumn{2}{|c|}{ Sum } & 1.86 & 3.21 & 3.45 & 3.32 & 3.12 & 3.27 & 3.30 & 3.35 & 3.37 & 3.08 & 31.33 \\
\hline \multirow{2}{*}{ New } & to North & 1.09 & 1.80 & 1.92 & 1.89 & 1.78 & 1.87 & 1.92 & 1.87 & 1.90 & 1.71 & 17.75 \\
\hline & to South & 1.03 & 1.87 & 2.02 & 1.90 & 1.79 & 1.86 & 1.86 & 1.96 & 1.95 & 1.80 & 18.04 \\
\hline \multicolumn{2}{|c|}{ Sum } & 2.13 & 3.67 & 3.94 & 3.79 & 3.57 & 3.73 & 3.77 & 3.83 & 3.85 & 3.52 & 35.79 \\
\hline
\end{tabular}

Table 5 - Monetary value of travel time for private cars $[€ / h]$

\begin{tabular}{||c|c|c|c|c|c|c|c|c|c|c|c|c||}
\hline \multicolumn{2}{|c|}{} & $6: 00$ & $7: 00$ & $8: 00$ & $9: 00$ & $14: 00$ & $15: 00$ & $16: 00$ & $17: 00$ & $18: 00$ & $19: 00$ & Sum \\
\hline \hline \multirow{2}{*}{ Old } & to North & 673 & 1,108 & 1,185 & 1,167 & 1,097 & 1,153 & 1,182 & 1,153 & 1,169 & 1,057 & 10,944 \\
\cline { 2 - 13 } & to South & 638 & 1,156 & 1,244 & 1,171 & 1,103 & 1,148 & 1,144 & 1,207 & 1,203 & 1,112 & 11,126 \\
\hline \multicolumn{2}{|c|}{ Sum } & 1,311 & 2,264 & 2,429 & 2,338 & 2,200 & 2,302 & 2,326 & 2,360 & 2,372 & 2,169 & 22,071 \\
\hline \multirow{2}{*}{ New } & to North & 769 & 1,266 & 1,354 & 1,333 & 1,253 & 1,317 & 1,350 & 1,316 & 1,336 & 1,207 & 12,500 \\
\cline { 2 - 12 } & to South & 729 & 1,320 & 1,421 & 1,337 & 1,260 & 1,312 & 1,307 & 1,379 & 1,374 & 1,270 & 12,708 \\
\hline \multicolumn{2}{|c|}{ Sum } & 1,498 & 2,586 & 2,775 & 2,670 & 2,513 & 2,629 & 2,657 & 2,695 & 2,709 & 2,477 & 25,209 \\
\hline
\end{tabular}


travel time was $22,071 €$ on the daily basis but with new controlling policy it was $25,209 €$ on the daily basis.

The new approach has caused 3 minutes of travel time savings for the tram users. The estimated monetary gain would be $17,800 €$ on the daily level total based on the number of commuters and their value of travel time. The estimated costs are summarized in Figure 2.

Sensitivity analysis has been conducted (Table 6) in order to reveal the effect of input parameters such as cost factor of fuel $\left[€ /\right.$ litre] $\left(v_{j}\right)$, cost factor of $\mathrm{CO}_{2}\left[€ / \mathrm{tCO}_{2}\right](v)$, monetary value of travel time $[€ / \mathrm{h}](\tau)$

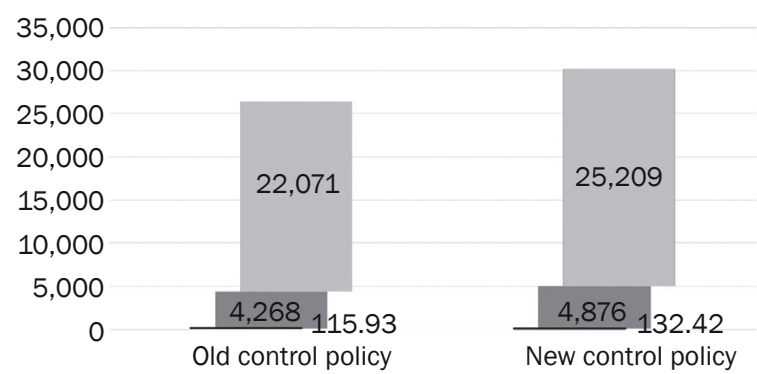

- Monetary value of travel time for passenger cars [ $€ / h]$

- Private cost of fuel consumption in red time in idle mode [€/h]

- Sum of $\mathrm{CO}_{2}$ emmision related costs/hour in red [€/h] (calculation was done $20 \mathrm{EUR} / \mathrm{tCO}_{2}$ )

Figure 2 - Estimated social costs

\section{CONCLUSION}

In this paper, the social costs of public transport supporting in Budapest were estimated. By applying the new policy of intersection controlling, travel time related costs for passenger cars, private cost of fuel consumption in red time in idle mode and $\mathrm{CO}_{2}$ emission related costs have been all increased by 3,138 euro, 608 euro and 16.49 euro per hour, respectively.

Although the investigated public transport support policy seems to be perfect at first glance, the derived results show the disagreement. In order to shift people toward public transportation, the "human-oriented transportation" policies might be an idea worth considering. In achieving this, the city leverages on the use of intelligent transportation systems (ITS) so as to provide high-quality transport infrastructure and improve services. The plan is to build a sustainable transportation system that centres on pedestrians. This entails providing safe, convenient transportation for the disabled, a pedestrian-oriented transportation environment, and low-cost, high-efficiency operation systems.

Although the costs were increased for private car users the cost structure did not change significantly due to the change of policy. Still, the emission-related estimated social costs are approximately $0.5 \%$ of the total, $16 \%$ of private costs surpluses due to increased fuel consumption and $83.5 \%$ of travel time and waiting-related estimated social costs. Besides, the estimated monetary gain of tram users would be 17,800 euro on a daily level. As previously mentioned, the costs of fuel consumption, travel time delay and $\mathrm{CO}_{2}$ emission all related to the increment of waiting time at intersections due to applying a public transport support policy were analysed in this paper. Considering the entire air pollution costs, the scope for the future research of the authors is adopting a fuel consumption function $F(V)$ where $V$ is the traffic speed in order to estimate the quantities of not just $\mathrm{CO}_{2}$ but the entire pollutants (e.g. VOC, $\mathrm{CO}, \mathrm{NO}_{\mathrm{x}}$, and $\mathrm{PM}_{10}$ ) which are generated by motor vehicles due to the waiting time increment at intersections. Besides, increased noise

Table 6 - Result of sensitivity analysis [€/h]

\begin{tabular}{|c|c|c|}
\hline & $\begin{array}{l}\text { Old Controlling } \\
\text { Policy }[€ / h]\end{array}$ & $\begin{array}{l}\text { New Controlling } \\
\text { Policy }[€ / h]\end{array}$ \\
\hline $\begin{array}{l}\text { Sum of } \mathrm{CO}_{2} \text { emission related costs/hour in red, }[€ / \mathrm{h}] \\
\text { (calculation was done on } 20 \mathrm{EUR} / \mathrm{tCO}_{2} \text { ) }\end{array}$ & 116 & 132 \\
\hline $\begin{array}{l}\text { Sum of } \mathrm{CO}_{2} \text { emission related costs/hour in red, }[€ / \mathrm{h}] \\
\text { (calculation was done on } 10 \mathrm{EUR} / \mathrm{tCO}_{2} \text { ) }\end{array}$ & 58 & 66 \\
\hline $\begin{array}{l}\text { Sum of } \mathrm{CO}_{2} \text { emission related costs/hour in red, [€/h] } \\
\text { (calculation was done on } 5 \mathrm{EUR} / \mathrm{t} \mathrm{CO}_{2} \text { ) }\end{array}$ & 29 & 33 \\
\hline $\begin{array}{l}\text { Private costs of fuel cosumption in red time in idle mode [€/h] } 1 \text { litre Gasoline: } 300 \mathrm{Ft} \text {; } \\
1 \text { liter disel oil: } 300 \mathrm{Ft}\end{array}$ & 2,999 & 3,426 \\
\hline $\begin{array}{l}\text { Private costs of fuel cosumption in red time in idle mode [€/h] } 1 \text { litre Gasoline: } 424 \mathrm{Ft} \text {; } \\
1 \text { liter disel oil: } 431 \mathrm{Ft}\end{array}$ & 4,268 & 4,876 \\
\hline $\begin{array}{l}\text { Private costs of fuel cosumption in red time in idle mode [€/h] } 1 \text { litre Gasoline: } 500 \mathrm{Ft} \text {; } \\
1 \text { liter disel oil: } 500 \mathrm{Ft}\end{array}$ & 4,998 & 5,710 \\
\hline Monetary value of travel time for Passenger cars [€/h] (VTT: $6 € / h)$ & 22,071 & 25,209 \\
\hline Monetary value of travel time for Passenger cars [€/h] (VTT: $8 € / h)$ & 29,428 & 33,612 \\
\hline Monetary value of travel time for Passenger cars $[€ / \mathrm{h}](\mathrm{VTT}: 10 € / \mathrm{h})$ & 36,785 & 42,015 \\
\hline
\end{tabular}


costs by calculating the reduction in the value of residential units alongside the investigation area which tend to abate with distance can be incorporated in further analysis to see whether this $13.7 \%$ waiting time increase has any effect on noise costs or not. Also, the impact of the so-called local pollutants on human health both in terms of mortality (i.e. reducing life expectancy) and morbidity (i.e. affecting the quality of life) can be analysed further.

\section{ACKNOWLEDGEMENT}

Authors gratefully acknowledge the support of the Hungarian Academy of Science, the support of János BÓLYAI Scholarship.

MOHAMMAD MAGHROUR ZEFREH, doktorandusz ${ }^{1}$

E-mail: mohammad.maghrour@mail.bme.hu

FERENC MESZAROS, Ph.D., docens ${ }^{1}$

E-mail: fmeszaros@kgazd.bme.hu

RAIMUNDAS JUNEVIČIUS, Ph.D., docens ${ }^{2}$

E-mail: raimundas.junevicius@vgtu.It

ADAM TOROK, Ph.D. Ing.,Ph.D., adjunktus ${ }^{1}$

(Corresponding author)

E-mail: atorok@kgazd.bme.hu

${ }^{1}$ Budapesti Múszaki és Gazdaságtudományi Egyetem, Közlekedésüzemi és Közlekedésgazdasági Tanszék

Stoczek utca 2, 1111 Budapest, Magyarország

2 Vilnius Gediminas Múszaki Egyetem,

Közlekedési Műszaki Eszközök Tanszék

J. Basanavičiaus str. 28, 03224 Vilnius, Lithuania

\section{KÖZFORGALMI KÖZÖSSÉGI KÖZLEKEDÉS ELŐNYBE RÉSZÉSEÍTÉSÉNEK GAZDASÁGI ELEMZÉSE: BUDA- PESTI ESETTANULMÁNY}

\section{ABSZTRAKT}

Ebben a cikkben a szerzők a budapesti körúti villamos elöyberészesítésének társadalmi-gazdasági vizsgálatát végezték el. Cikkükben a szerzôk rávilágítanak, hogy a közforglmú közösségi közlekedés priorítása némely esetben megkérdôjelezhetô. Az elemzés rámutatott, hogy az egyéni személygépjármúvek $\mathrm{CO}_{2}$ kibocsátása 14.2 \%-kal a várakozásból származó társadalmi kiadások pedig 13.7 \%-kal növekedtek. Ezzel szemben a villamoshazsnálók napi nyeresége $17800 €$, ami az utazási idô rövidülésébôl származik.

\section{KULCSSZAVAK}

Közforgalmú közösségi közlekedés elönybe részesitése; társadalmi költség; csomópont irányitás; $\mathrm{CO}_{2}$ kibocsátási költség;

\section{REFERENCES}

[1] Holmgren J. A Strategy for Increased Public Transport Usage - The Effects of Implementing a Welfare Maximizing Policy. Research in Transportation Economics. 2014;48:221-26. doi:10.1016/j.retrec.2014.09.046
[2] Ramjerdi F, Fearnley N. Risk and irreversibility of transport interventions. Transportation Research Part A: Policy and Practice. 2014;60:31-39.

[3] Justen A, Schippl J, Lenz B, Fleischer B. Assessment of Policies and Detection of Unintended Effects: Guiding Principles for the Consideration of Methods and Tools in Policy-Packaging. Transportation Research Part A: Policy and Practice. 2014;60:19-30. doi:10.1016/ j.tra.2013.10.015

[4] Tobollik M, Keuken M, Sabel C, et al. Health Impact Assessment of Transport Policies in Rotterdam: Decrease of Total Traffic and Increase of Electric Car Use. Environmental Research. 2016;146:350-58. doi:10.1016/j.envres.2016.01.014

[5] Verma A, Rahul TM, Dixit M. Sustainability Impact Assessment of Transportation Policies - A Case Study for Bangalore City. Case Studies on Transport Policy. 2015;3(3):321-30. doi:10.1016/j.cstp.2014.06.001

[6] Sun H, Zhang Y, Wang Y, Li L, Sheng Y. A Social Stakeholder Support Assessment of Low-Carbon Transport Policy Based on Multi-Actor Multi-Criteria Analysis: The Case of Tianjin. Transport Policy. 2015;41:103-16. doi:10.1016/ j.tranpol.2015.01.006

[7] Crisalli U, Comi A, Rosati A. A Methodology for the Assessment of Rail-road Freight Transport Policies. Procedia - Social and Behavioral Sciences. 2013;87: 292-305. doi:10.1016/j.sbspro.2013.10.611

[8] Wang Y, Monzon A, Di Ciommo F. Assessing the Accessibility Impact of Transport Policy by a LandUse and Transport Interaction Model - The Case of Madrid. Computers, Environment and Urban Systems. 2015;49:126-35. doi:10.1016/j.compenvurbsys.2014.03.005

[9] European Commission. White paper 2011: Roadmap to a Single European Transport Area - Towards a Competitive, and Resource Efficient Transport System [homepage on the Internet]. 2011. Available from: http://ec.europa.eu/transport/themes/strategies/2011_white_paper_en

[10] Wei Y, Huang C, Lam PT, Yuan Z. Sustainable urban development: A review on urban carrying capacity assessment. Habitat International. 2015;46:64-71. doi: 10.1016/j.habitatint.2014.10.015

[11] Černý J, Černá A, Bohdan L. Support of decision-making on economic and social sustainability of public transport. Transport, 2014;29(1):59-68. doi: 10.3846/16484142.2014.897645

[12] Toşa C, Antov D, Köllő G, Rõuk H, Rannala M. A methodology for modelling traffic related emissions in suburban areas. Transport. 2015;30(1):80-87. doi: 10.3846/16484142.2013.819034

[13] Gaal G, Horváth E, Török Á, Csete M. Analysis of Public Transport Performance in Budapest, Hungary. Periodica Polytechnica: Social and Management Sciences. 2015;23(1):68-72. doi: 10.3311/PPso.7724

[14] European Commission. White paper: European transport policy for 2010: time to decide [homepage on the Internet]. 2001. Available from: http://ec.europa.eu/ transport/themes/strategies/doc/2001_white_paper/lb_com_2001_0370_en.pdf

[15] European Commission. White paper: Roadmap to a Single European Transport Area - Towards a competitive 
and resource efficient transport system [homepage on the Internet]. 2010. Available from: http://eur-lex.europa.eu/LexUriServ/LexUriServ. do?uri=COM:2011:0144:FIN:en:PDF

[16] Masoumi HE, Soltanzadeh H. A Regional Analysis Of Urban Population And Transport Energy Consumption. International Journal for Traffic \& Transport Engineering. 2014;4(4):372-385. doi: 10.7708/ijtte.2014.4(4).02

[17] Fátima Teles M, Sousa JF. Environmental Management and Business Strategy: Structuring the Decision-Making Support in a Public Transport Company. Transportation Research Procedia. 2014;3:155-164. doi:10.1016/j.trpro.2014.10.101

[18] Mori U, Mendiburu A, Álvarez M, Lozano JA. A review of travel time estimation and forecasting for Advanced Traveller Information Systems. Transportmetrica A: Transport Science. 2015;11(2):119-157. doi: 10.1080/23249935.2014.932469

[19] Zhou Z, Cai M. Intersection Signal Control Multi-Objective Optimization Based on Genetic Algorithm. Journal of Traffic and Transportation Engineering. 2014;1(2):153158. doi: 10.1016/S2095-7564(15)30100-8

[20] Lämmer S, Kori H, Peters K, Helbing D. Decentralised Control of Material or Traffic Flows in Networks Using Phase-Synchronisation. Physica A: Statistical Mechanics and Its Applications. 2006;363(1):39-47. doi:10.1016/j.physa.2006.01.047

[21] Smits ES, Bliemer MCJ, Pel AJ, van Arem B. A Family of Macroscopic Node Models. Transportation
Research Part B: Methodological. 2015;74(4):20-39. doi:10.1016/j.trb.2015.01.002

[22] Index.hu. Cost of intersection controlling [homepage on the Internet]. In Hungarian: Nagykörúti lámpahangolás. 2012. Available from: http://index.hu/belfold/budapest/2012/02/06/44_millioba_kerult_a_ lampaathangolas/ last visit: April 5. 2015

[23] Ozbay K, Bartin B, Yanmaz-Tuzel O, Berechman J. Alternative Methods for Estimating Full Marginal Costs of Highway Transportation. Transportation Research Part A: Policy and Practice. 2007;41(8):768-86. doi:10.1016/j.tra.2006.12.004

[24] Flügel S. Accounting for User Type and Mode Effects on the Value of Travel Time Savings in Project Appraisal: Opportunities and Challenges. Research in Transportation Economics. 2014;47:50-60. doi:10.1016/j. retrec.2014.09.018

[25] Uchida K. Estimating the Value of Travel Time and of Travel Time Reliability in Road Networks. Transportation Research Part B: Methodological. 2014;66:12947. doi:10.1016/j.trb.2014.01.002

[26] Meszaros F, Torok A. Theoretical Investigation of Emission and Delay Based Intersection Controlling and Synchronising in Budapest. Periodica Polytechnica: Transportation Engineering. 2014;42(1):37-42. doi: 10.3311/PPtr.7183

[27] European Commission. Action Plan for Energy Efficiency. $\operatorname{COM}(2006) 545$ [homepage on the Internet]. 2008. Available from: http://eur-lex.europa.eu/legal-content/EN/TXT/?uri=CELEX\%3A52006DC0545 